Malaysian Journal of Social Sciences and Humanities (MJSSH)

Volume 4, Issue 8, December 2019

e-ISSN : 2504-8562

Journal home page:

www.msocialsciences.com

\title{
Teknik Peer Instruction dengan Analisis Sumber-Sumber Sejarah: Kekekalan Kemahiran Pemikiran Kritikal?
}

\author{
M. Kaviza ${ }^{1}$ \\ 1Pusat Pengajian Pendidikan dan Bahasa Moden, Universiti Utara Malaysia (UUM) \\ Correspondence: M. Kaviza (kavizakaviza@yahoo.com)
}

\begin{abstract}
Abstrak
Kajian eksperimental ini bertujuan untuk mengenal pasti kesan teknik Peer Instruction dengan analisis sumber-sumber sejarah terhadap kekekalan kemahiran berfikir kritikal. Seramai 25 orang murid Tingkatan Empat melalui teknik persampelan bertujuan terlibat dalam kajian ini. Instrumen ujian pemikiran kritikal yang diadaptasi yang telah disahkan pakar penilai dan mempunyai nilai kebolehpercayaan yang baik merupakan instrumen kajian ini. Data kajian ini dianalisis secara inferensi iaitu ujian ANOVA Satu Hala dengan pengukuran berulang melalui perisian IBM SPSS. Dapatan kajian ini menunjukkan bahawa teknik Peer Instruction dengan analisis sumber-sumber sejarah adalah berkesan terhadap kekekalan kemahiran berfikir kritikal dalam kalangan murid. Implikasi kajian ini telah mencadangkan kepada guru-guru Sejarah pada semua peringkat persekolahan untuk melaksanakan teknik Peer Instruction dengan analisis sumber-sumber sejarah untuk memupuk kemahiran berfikir kritikal yang beterusan dalam kalangan murid.
\end{abstract}

Kata kunci: kemahiran berfikir kritikal, sumber-sumber sejarah, teknik peer instruction

\section{Historical Sources Analysis with Peer Instruction Technique: Retention of Critical Thinking Skills?}

\begin{abstract}
This experimental study aims to identify the effect of Peer Instruction techniques with historical sources analysis on retention of critical thinking skills. A total 25 form fours through purposive sampling techniques involved in this study. An adapted critical thinking test has been validated by the content expert matter and has a good reliability used as research instrument in this study. The data of this study were analyzed inference statistic via one ways ANOVA with repeated measures test using IBM SPSS software. The findings of this study showed that Peer Instruction technique with historical sources analysis retent critical thinking effectively. The implications of this study have been suggested to history teachers to implement Peer Instruction techniques with historical sources analysis to develop and retent critical thinking skills among students.
\end{abstract}

Keywords: critical thinking skills, historical sources, peer instruction techniques 


\section{Pengenalan}

Peningkatan taraf mata pelajaran sejarah sebagai mata pelajaran wajib lulus pada peringkat peperiksaan awam telah menyarankan kepada inovasi dalam kaedah pengajaran sejarah yang menekankan kepada pemupukan elemen kemahiran befikir kritikal yang merupakan salah satu saranan dalam aspirasi negara melalui Pelan Pembangunan Pendidikan Malaysia 2013- 2025 (Kementerian Pendidikan Malaysia (KPM, 2013). Hal ini kerana sistem pendidikan Malaysia perlu mempersiapkan murid-murid yang berani menghadapi cabaran masa depan, menyelesaikan konflik secara aman, membuat keputusan yang wajar dalam situasi kritikal dan mempunyai keberanian melakukan tindakan yang benar (Rosnani Hashim, 2002; KPM, 2013). Sehubungan dengan itu, pendidikan sejarah juga telah mengalami reformasi bagi mencapai objektif kurikulum jangka panjangnya dalam mengaplikasikan kemahiran berfikir aras tinggi dalam melahirkan murid untuk bersaing di peringkat global dengan memahami dan peka dengan ilmu sejarah (Pusat Perkembangan Kurikulum (PPK), 2003). Hal ini kerana ilmu sejarah merupakan kajian-kajian lepas yang telah dibuktikan dengan menggunakan sumber sejarah dalam menjelaskan sesuatu perkara atau kandungannya secara kritikal (Patterson, Lucas \& Kithinji, 2012; Barton, 2005; Waring \& Robinson, 2011; Edmonds, Hull, Janik, \& Rylance, 2005). Tambahan pula, terdapat pelbagai jenis sumber sejarah sepeti enskliopedia, majalah, surat khabar, jurnal, buku sejarah dan sebagainya yang dapat digunakan dalam proses pengajaran dan pembelajaran yang dapat melatih murid-murid untuk membuat penaakulan yang wajar, di samping bertujuan untuk melahirkan muridmurid yang berinfomasi sejarah.

Oleh kerana kemahiran berfikir kritikal merupakan suatu proses penilaian evidens dan memeriksa kriteria yang relevan untuk membuat suatu pertimbangan yang melibatkan aspek logik, kejelasan, kredibiliti, ketepatan, kejituan, kerelevanan, kedalaman, dan sebagainya dalam memerihalkan sesuatu isu atau penyelesaian, maka murid-murid dapat meningkatkan kefahaman epistemologi mereka dengan mengenal pasti isu utama dan membuat andaian untuk dibahaskan, mengenal pasti hubungan, membuat inferens daripada maklumat dan seterusnya membuat interpretasi kesimpulan dan menilai bukti (Herreid, Schiller \& Herreid, 2012; Gough, 1991; Mulnix, 2010; Hamidah Maidinsah, Farah Nabillah, Mohamed Jizad, Maslizah Ab. Wahab \& Balkish Osman, 2019). Pendapat ini adalah bertepatan kerana pemikiran kritikal perlulah melibatkan elemen membuat inferens yang merupakan langkah awal yang perlu diambil oleh seseorang untuk membuat kesimpulan sama ada ianya adalah benar atau tidak berdasarkan pemerhatian teliti yang dilakukan bagi mengenal pasti andaian dan mengaplikasikan kemahiran seperti membuat deduksi, membuat interpretasi dan menilai hujah (Watson \& Glaser, 1980; Karma \& Ghida, 2007). Justeru, kemahiran berfikir kritikal perlu melibatkan kebolehan untuk menrefleks dan mensistesis maklumat bagi membolehkan murid dapat membuat penambahbaikan kepada proses pembelajaran mereka sendiri yang telah mencadangkan kepada teknik pembelajaran yang sesuai dalam pendidikan sejarah yang perlu dilaksanakan.

Melalui pembelajaran berasaskan teknik Peer Instruction, kemahiran intelektual untuk menilai dan mempertimbangkan sesuatu perkara, meningkatkan keupayaan dan kefahaman serta mengekalkan kematangan yang dikaitkan dengan ciri-ciri kemahiran berfikir adalah berpotensi dibentuk dalam kalangan murid melalui proses pembelajaran (Beyer, 1995; Herrnstein, Nickerson, Sanchez \& Swetz, 1986; Snyder \& Snyder, 2008; Halpern, 1998). Hal ini kerana teknik Peer Instruction yang telah diasaskan oleh Mazur (1997) merupakan strategi pembelajaran konstruktivis yang berprinsipkan penyertaan murid secara aktif dan menggalakkan berkolaborasi antara rakan-rakan di dalam kelas (Crouch \& Mazur, 2001; Van Den, Admiral \& Pilot, 2006; Burkholder, 2014; Sullivan, 2009). Sehubungan dengan itu, adalah diakui bahawa teknik Peer Instruction telah pun dipraktikkan secara meluas dalam bidang pendidikan Sains, khususnya dalam mata pelajaran Fizik serta telah dibuktikan keberkesanannya terhadap penjanaan kefahaman konseptual, penyelesaian masalah dan motivasi dalam kalangan murid pada semua peringkat pendidikan (Lasry, Mazur \& Watkins, 2008; Tolga, 2012; Lucas, 2009; Cortright, Collins \& DiCarlo, 2005; Rao \& DiCarlo, 2000). Namun, pelaksanaan teknik Peer Instruction dalam pendidikan sejarah melalui analisis sumber sejarah adalah disarankan disebabkan ia berpotensi untuk memberi ruang dan peluang pembelajaran kepada murid-murid untuk berfikir secara kritikal mengenai sesuatu maklumat yang dipaparkan dalam sumber-sumber sejarah bagi membolehkan mereka dapat berbincang dengan rakan-rakan di dalam kelas dengan mengaplikasikan proses pemikiran secara efektif bagi membuat suatu kefahaman sejarah yang baik dan 
mendalam. Justeru, keberkesanan teknik Peer Instruction yang disepadukan dengan proses analisis sumber-sumber sejarah terhadap kekekalan kemahiran berfikir kritikal masih belum diketahui walaupun tahap kemahiran berfikir kritikal dalam kalangan murid adalah dilaporkan masih berada antara tahap rendah dan sederhana sahaja (Sarimah Kamrin \& Shaharom Noordin, 2008; Nurul Shida Noni \& Abdul Halim Abdullah, 2018; Mohd Rozaidi Ismail, Roslina Abdul Aziz \& Zamnah Husin, 2007; Mohd Fadzil Mohd Rosdi, Suhaida Abdul Kadir \& Mohd Ibrahim Nazri, 2017). Oleh itu terdapat satu keperluan dalam kajian ini untuk mengkaji kesan teknik Peer Instruction dengan analisis sumber-sumber sejarah terhadap kekekalan kemahiran berfikir kritikal dalam kalangan murid.

\section{Objektif Kajian}

Secara umumnya, kajian ini diharapkan dapat menjawab objektif kajian berikut:

i. Mengenal pasti sama ada teknik Peer Instruction dengan analisis sumber-sumber sejarah berkesan terhadap kekekalan kemahiran pemikiran kritikal.

ii. Mengenal pasti sama ada teknik Peer Instruction dengan analisis sumber-sumber sejarah berkesan terhadap kekekalan konstruk membuat inferens.

iii. Mengenal pasti sama ada teknik Peer Instruction dengan analisis sumber-sumber sejarah berkesan terhadap kekekalan konstruk mengusul periksa andaian.

iv. Mengenal pasti sama ada teknik Peer Instruction dengan analisis sumber-sumber sejarah berkesan terhadap kekekalan konstruk membuat deduksi.

v. Mengenal pasti sama ada teknik Peer Instruction dengan analisis sumber-sumber sejarah berkesan terhadap kekekalan konstruk membuat interpretasi.

vi. Mengenal pasti sama ada teknik Peer Instruction dengan analisis sumber-sumber sejarah berkesan terhadap kekekalan konstruk penilaian hujah.

\section{Soalan Kajian}

Secara khususnya, kajian ini diharapkan dapat menjawab soalan kajian berikut:

i. Adakah teknik Peer Instruction dengan analisis sumber-sumber sejarah berkesan terhadap kekekalan kemahiran pemikiran kritikal?

ii. Adakah teknik Peer Instruction dengan analisis sumber-sumber sejarah berkesan terhadap kekekalan konstruk membuat inferens?

iii. Adakah teknik Peer Instruction dengan analisis sumber-sumber sejarah berkesan terhadap kekekalan konstruk mengusul periksa andaian?

iv. Adakah teknik Peer Instruction dengan analisis sumber-sumber sejarah berkesan terhadap kekekalan konstruk membuat deduksi?

v. Adakah teknik Peer Instruction dengan analisis sumber-sumber sejarah berkesan terhadap kekekalan konstruk membuat interpretasi?

vi. Adakah teknik Peer Instruction dengan analisis sumber-sumber sejarah berkesan terhadap kekekalan konstruk penilaian hujah?

\section{Hipotesis Kajian}

Bagi menjawab soalan kajian di atas, maka hipotesis nul kajian berikut telah diuji:

$\mathrm{H}_{\mathrm{ol}}$ : Tidak terdapat perbezaan yang signifikan antara ujian pra, ujian pasca dan ujian lanjutan terhadap min kemahiran pemikiran kritikal.

$\mathrm{H}_{\text {ola }}$ : Tidak terdapat perbezaan yang signifikan antara ujian pra, ujian pasca dan ujian lanjutan terhadap min konstruk membuat inferens. 
$\mathrm{H}_{\mathrm{olb}}$ : Tidak terdapat perbezaan yang signifikan antara ujian pra, ujian pasca dan ujian lanjutan terhadap min konstruk mengusul periksa andaian.

$\mathrm{H}_{\mathrm{olc}}$ : Tidak terdapat perbezaan yang signifikan antara ujian pra, ujian pasca dan ujian lanjutan terhadap min konstruk membuat deduksi.

$\mathrm{H}_{\text {old }}$ : Tidak terdapat perbezaan yang signifikan antara ujian pra, ujian pasca dan ujian lanjutan terhadap min konstruk membuat interpretasi.

$\mathrm{H}_{\mathrm{ole}}$ : Tidak terdapat perbezaan yang signifikan antara ujian pra, ujian pasca dan ujian lanjutan terhadap min konstruk penilaian hujah.

\section{Metod Kajian}

Kajian eksperimental dengan rekabentuk Pre-Experimental Design: One Group Pretest-Posttest Design (Cohen, Manion \& Morrison, 2007) ini melibatkan 25 orang murid Tingkatan Empat melalui teknik persampelan bertujuan dari sebuah sekolah menengah harian di utara Semenanjung Malaysia. Instrumen kajian ini merupakan ujian pemikiran kritikal yang diadaptasi yang telah disahkan oleh dua orang pakar penilai serta mempunyai nilai ketekalan dalaman iaitu 0.96 yang dianggap baik (Nunnally, 1978). Data ujian pemikiran kritikal diukur melalui ujian pra, ujian pasca dan ujian lanjutan. Data kajian ini telah dianalisis secara deskriptif dan inferensi iaitu ANOVA Satu Hala dengan Pengukuran Berulang melalui perisian IBM SPSS Statistic. Murid-murid mengikuti pengajaran dan pembelajaran Sejarah bagi topik Perkembangan di Eropah dalam kajian ini.

\section{Dapatan Kajian}

Dapatan kajian bagi menjawab soalan kajian 1 dan konstruk-konstruknya adalah seperti berikut.

\section{Soalan kajian 1:}

Adakah teknik Peer Instruction dengan sumber-sumber sejarah berkesan terhadap kekekalan kemahiran pemikiran kritikal?

Min ujian pasca kemahiran pemikiran kritikal $(M=66.24, S D=13.74)$ adalah lebih tinggi berbanding dengan min ujian pra $(M=25.04, S D=8.32)$ dan ujian lanjutan $(M=50.52, S D=6.88)$. Keputusan ujian Multivariate pada Jadual 1 menunjukkan terdapat kesan ujian terhadap kemahiran pemikiran kritikal yang signifikan (Wilks Lambda $=0.69, F(2,23)=154.45, \mathrm{p}<0.05, \pi^{2}=0.93$ ) iaitu saiz kesan sangat besar (Cohen, 1988). Di samping itu, keputusan ujian kesferaan Mauchly yang tidak signifikan $(p=0.16)$ pada Jadual 2 menunjukkan bahawa andaian kesferaan matriks varians adalah dipatuhi, maka keputusan ujian univariate pada Jadual 3 menunjukkan bahawa terdapat kesan ujian yang signifikan terhadap kemahiran pemikiran kritikal $\left(F(2,48)=143.26, \mathrm{p}<0.05, \pi^{2}=0.86\right)$. Seterusnya, dapatan ujian Post Hoc Bonferroni pada Jadual 4 menunjukkan bahawa terdapat perbezaan yang signifikan antara ujian pra, ujian pasca dan ujian lanjutan terhadap min kemahiran pemikiran kritikal. Oleh itu, hipotesis nol $\mathrm{H}_{\mathrm{ol}}$ berjaya ditolak iaitu terdapat perbezaan yang signifikan antara ujian pra, ujian pasca dan ujian lanjutan terhadap min kemahiran pemikiran kritikal. Maka, terdapat kesan kekekalan terhadap kemahiran pemikiran kritikal dalam kajian ini.

Jadual 1: Keputusan Ujian Multivariate untuk Min Kemahiran Pemikiran Kritikal

\begin{tabular}{|c|c|c|c|c|c|c|c|}
\hline Kesan & & Nilai & $F$ & $\begin{array}{l}\text { Hipotesis } \\
d f\end{array}$ & $\begin{array}{c}\text { Ralat } \\
\quad d f\end{array}$ & $p$ & $\begin{array}{c}\text { Partial eta } \\
\text { squared }\end{array}$ \\
\hline Kritikal & $\begin{array}{c}\text { Wilks' } \\
\text { Lambda }\end{array}$ & 0.69 & 154.45 & 2.00 & 23.00 & 0.00 & 0.93 \\
\hline
\end{tabular}


Jadual 2: Keputusan ujian Mauchly's $W$ Min Kemahiran Pemikiran Kritikal

\begin{tabular}{|c|c|c|c|c|c|c|c|}
\hline \multirow{2}{*}{$\begin{array}{l}\text { Kesan } \\
\text { dalam } \\
\text { subjek }\end{array}$} & \multirow{2}{*}{$\begin{array}{c}\text { Mauchly's } \\
W\end{array}$} & \multirow{2}{*}{$\begin{array}{l}\text { Khi kuasa } \\
\quad \text { dua }\end{array}$} & \multirow[t]{2}{*}{$d f$} & \multirow[t]{2}{*}{$p$} & \multicolumn{3}{|c|}{ Epsilon } \\
\hline & & & & & $\begin{array}{l}\text { Greenhouse- } \\
\text { Geisser }\end{array}$ & $\begin{array}{l}\text { Huynh- } \\
\text { Feldt }\end{array}$ & $\begin{array}{l}\text { Lower- } \\
\text { bound }\end{array}$ \\
\hline Ujian & 0.85 & 3.67 & 2 & 0.16 & 0.87 & 0.93 & 0.50 \\
\hline
\end{tabular}

Pada aras kesignifikan 0.05

Jadual 3: Keputusan Ujian Univariate untuk Min Kemahiran Pemikiran Kritikal

\begin{tabular}{clcccccc}
\hline Kesan & & $\begin{array}{c}\text { Jumlah } \\
\text { kuasa Dua } \\
\text { Jenis III }\end{array}$ & df & $\begin{array}{c}\text { Kuasa } \\
\text { dua min }\end{array}$ & $\boldsymbol{F}$ & $\boldsymbol{p}$ & $\begin{array}{c}\text { Partial } \\
\text { eta } \\
\text { squared }\end{array}$ \\
\hline Kritikal & $\begin{array}{l}\text { Andaian } \\
\text { dipatuhi }\end{array}$ & 21614.91 & 2 & 10807.45 & 143.26 & 0.00 & 0.86 \\
\hline Ralat & 3621.09 & 48 & 75.44 & & & \\
\hline
\end{tabular}

Jadual 4: Keputusan Ujian Post Hoc Bonferroni Min Kemahiran Pemikiran Kritikal

\begin{tabular}{llccccc}
\hline & & $\begin{array}{c}\text { Perbezaan } \\
\text { Min }\end{array}$ & Ralat & $\boldsymbol{p}$ & \multicolumn{2}{c}{$\begin{array}{c}\text { 95\% selang } \\
\text { keyakinan bagi } \\
\text { perbezaan }\end{array}$} \\
\cline { 5 - 7 } & & & & & \multicolumn{2}{c}{$\begin{array}{c}\text { Atas } \\
\text { Bawah }\end{array}$} \\
\hline Ujian Pra & Ujian Pasca & -41.20 & 2.63 & 0.00 & -47.96 & -34.44 \\
& Ujian Lanjutan & -25.48 & 1.93 & 0.00 & -30.46 & -20.50 \\
\hline Ujian Pasca & Ujian Pra & 41.20 & 2.63 & 0.00 & 34.44 & 47.96 \\
& Ujian Lanjutan & 15.72 & 2.73 & 0.00 & 8.69 & 22.76 \\
\hline Ujian Lanjutan & Ujian Pra & 25.48 & 1.93 & 0.00 & 20.50 & 30.46 \\
& Ujian Pasca & -15.72 & 2.73 & 0.00 & -22.76 & -8.69 \\
\hline
\end{tabular}

Berdasarkan estimated marginal means

*Perbezaan min adalah signifikan pada aras 0.05

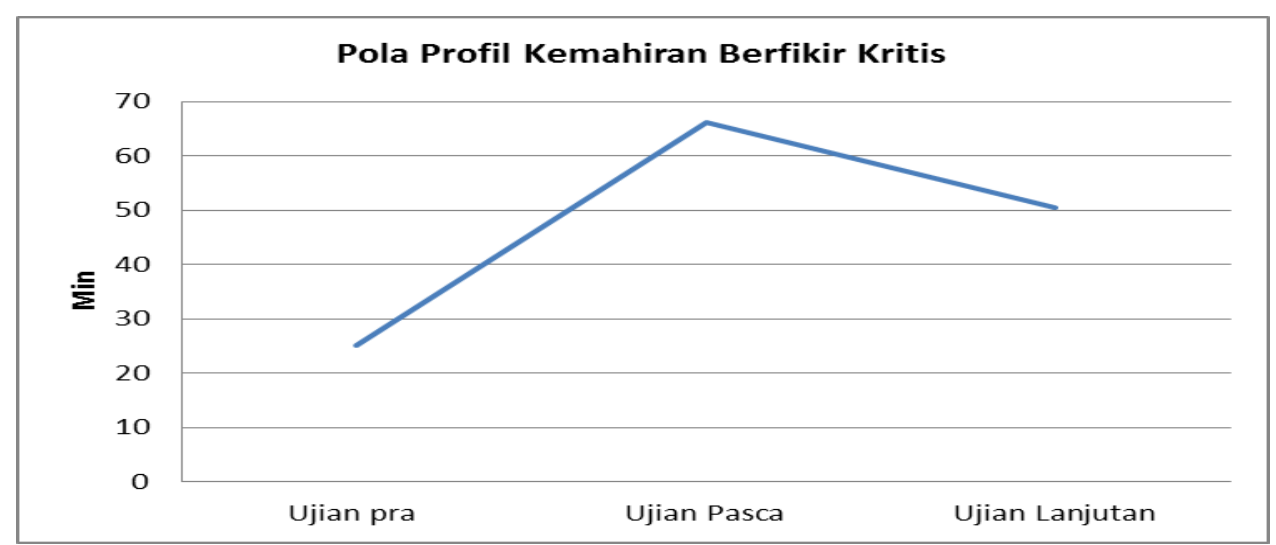

Rajah 1: Graf Pola Profil Kemahiran Pemikiran Kritikal 


\section{Konstruk membuat inferens}

Min ujian pasca konstruk membuat inferens $(M=13.72, S D=2.44)$ adalah lebih tinggi berbanding dengan min ujian pra $(M=5.48, S D=2.14)$ dan ujian lanjutan $(M=10.24, S D=1.61)$. Keputusan ujian Multivariate pada Jadual 5 menunjukkan terdapat kesan ujian terhadap konstruk membuat inferens yang signifikan (Wilks Lambda $=0.11, F(2,23)=92.24, \mathrm{p}<0.05, \pi^{2}=0.89$ ) iaitu saiz kesan sangat besar (Cohen, 1988). Di samping itu, keputusan ujian kesferaan Mauchly yang tidak signifikan $(p=0.65)$ pada Jadual 6 menunjukkan bahawa andaian kesferaan matriks varians adalah dipatuhi, maka keputusan ujian univariate pada Jadual 7 menunjukkan bahawa terdapat kesan ujian yang signifikan terhadap konstruk membuat inferens $\left(F(2,48)=112.54, \mathrm{p}<0.05, \pi^{2}=0.82\right)$. Seterusnya, dapatan ujian Post Hoc Bonferroni pada Jadual 8 menunjukkan bahawa terdapat perbezaan yang signifikan antara ujian pra, ujian pasca dan ujian lanjutan terhadap min konstruk membuat inferens. Oleh itu, hipotesis nol $\mathrm{H}_{\mathrm{ola}}$ berjaya ditolak iaitu terdapat perbezaan yang signifikan antara ujian pra, ujian pasca dan ujian lanjutan terhadap min konstruk membuat inferen. Maka, terdapat kesan kekekalan terhadap konstruk membuat inferens dalam kajian ini.

Jadual 5: Keputusan Ujian Multivariate untuk Min Konstruk Membuat Inferens

\begin{tabular}{cccccccc}
\hline Kesan & Nilai & $\boldsymbol{F}$ & $\begin{array}{c}\text { Hipotesis } \\
\boldsymbol{d f}\end{array}$ & $\begin{array}{c}\text { Ralat } \\
\boldsymbol{d} \boldsymbol{f}\end{array}$ & $\boldsymbol{p}$ & $\begin{array}{c}\text { Partial eta } \\
\text { squared }\end{array}$ \\
\hline Inferens & Wilks' & 0.11 & 92.24 & 2.00 & 23.00 & 0.00 & 0.89 \\
& Lambda & & & & & & \\
\hline
\end{tabular}

Jadual 6: Keputusan ujian Mauchly's W Min Konstruk Membuat Inferens

\begin{tabular}{cccccccc}
\hline $\begin{array}{c}\text { Kesan } \\
\text { dalam } \\
\text { subjek }\end{array}$ & $\begin{array}{c}\text { Mauchly's } \\
\boldsymbol{W}\end{array}$ & $\begin{array}{c}\text { Khi kuasa } \\
\text { dua }\end{array}$ & df & $\boldsymbol{p}$ & \multicolumn{3}{c}{\begin{tabular}{c} 
Epsilon \\
\cline { 5 - 7 }
\end{tabular}} \\
\hline Ujian & 0.96 & 0.86 & 2 & 0.65 & 0.96 & 1.00 & 0.50 \\
\hline
\end{tabular}

Pada aras kesignifikan 0.05

Jadual 7: Keputusan Ujian Univariate untuk Min Konstruk Membuat Inferens

\begin{tabular}{llcccccc}
\hline Kesan & Jumlah & $\begin{array}{c}\text { Juasa Dua } \\
\text { kuasa } \\
\text { Jenis III }\end{array}$ & $\begin{array}{c}\text { Kuasa } \\
\text { dua min }\end{array}$ & $\boldsymbol{F}$ & $\boldsymbol{p}$ & $\begin{array}{c}\text { Partial } \\
\text { eta } \\
\text { squared }\end{array}$ \\
\hline Inferens & Andaian dipatuhi & 855.55 & 2 & 427.77 & 112.54 & 0.00 & 0.82 \\
\hline & Ralat & 182.45 & 48 & 3.80 & & &
\end{tabular}

Jadual 8: Keputusan Ujian Post Hoc Bonferroni Min Konstruk Membuat Inferens

\begin{tabular}{|c|c|c|c|c|c|c|}
\hline & & $\begin{array}{c}\text { Perbezaan } \\
\text { Min }\end{array}$ & Ralat & $P$ & $\begin{array}{r}95 \% \\
\text { keyak } \\
\text { per }\end{array}$ & $\begin{array}{l}\text { ang } \\
\text { bagi } \\
\text { an }\end{array}$ \\
\hline & & & & & Bawah & Atas \\
\hline Ujian Pra & Ujian Pasca & -8.24 & 0.60 & 0.00 & -9.79 & -6.70 \\
\hline & Ujian Lanjutan & -4.76 & 0.51 & 0.00 & -6.08 & -3.44 \\
\hline Ujian Pasca & Ujian Pra & 8.24 & 0.60 & 0.00 & 6.69 & 9.79 \\
\hline & Ujian Lanjutan & 3.48 & 0.54 & 0.00 & 2.10 & 4.86 \\
\hline
\end{tabular}




\begin{tabular}{llccccc}
\hline Ujian Lanjutan & Ujian Pra & 4.76 & 0.51 & 0.00 & 3.44 & 6.08 \\
& Ujian Pasca & -3.48 & 0.54 & 0.00 & -4.86 & -2.10 \\
\hline
\end{tabular}

Berdasarkan estimated marginal means

*Perbezaan min adalah signifikan pada aras 0.05

\section{Konstruk mengusul periksa andaian}

Min ujian pasca konstruk mengusul periksa andaian $(M=13.28, S D=3.01)$ adalah lebih tinggi berbanding dengan min ujian pra $(M=4.48, S D=1.98)$ dan ujian lanjutan $(M=10.60, S D=1.76)$. Keputusan ujian Multivariate pada Jadual 9 menunjukkan terdapat kesan ujian terhadap konstruk mengusul periksa andaian yang signifikan (Wilks Lambda $=0.08, F(2,23)=130.25 \mathrm{p}<0.05, \pi^{2}=0.92$ ) iaitu saiz kesan sangat besar (Cohen, 1988). Di samping itu, keputusan ujian kesferaan Mauchly yang tidak signifikan $(p=0.28)$ pada Jadual 10 menunjukkan bahawa andaian kesferaan matriks varians adalah dipatuhi, maka keputusan ujian univariate pada Jadual 11 menunjukkan bahawa terdapat kesan ujian yang signifikan terhadap konstruk mengusul periksa andaian $\left(F(2,48)=111.64, \mathrm{p}<0.05, \pi^{2}=0.82\right)$. Seterusnya, dapatan ujian Post Hoc Bonferroni pada Jadual 12 menunjukkan bahawa terdapat perbezaan yang signifikan antara ujian pra, ujian pasca dan ujian lanjutan terhadap min konstruk mengusul periksa andaian. Oleh itu, hipotesis nol $\mathrm{H}_{\mathrm{olb}}$ berjaya ditolak iaitu terdapat perbezaan yang signifikan antara ujian pra, ujian pasca dan ujian lanjutan terhadap min konstruk mengusul periksa andaian. Maka, terdapat kesan kekekalan terhadap konstruk mengusul periksa andaian dalam kajian ini.

Jadual 9: Keputusan Ujian Multivariate untuk Min Konstruk Mengusul Periksa Andaian

\begin{tabular}{cccccccc}
\hline Kesan & Nilai & $\boldsymbol{F}$ & $\begin{array}{c}\text { Hipotesis } \\
\boldsymbol{d f}\end{array}$ & $\begin{array}{c}\text { Ralat } \\
\boldsymbol{d} \boldsymbol{f}\end{array}$ & $\begin{array}{c}\boldsymbol{p} \\
\text { Partial eta } \\
\text { squared }\end{array}$ \\
\hline Andaian & Wilks' Lambda & 0.81 & 130.25 & 2.00 & 23.00 & 0.00 & 0.92 \\
\hline
\end{tabular}

Jadual 10: Keputusan ujian Mauchly’s W Min Konstruk Mengusul Periksa Andaian

\begin{tabular}{cccccccc}
\hline $\begin{array}{c}\text { Kesan } \\
\text { dalam } \\
\text { subjek }\end{array}$ & $\begin{array}{c}\text { Mauchly's } \\
\boldsymbol{W}\end{array}$ & $\begin{array}{c}\text { Khi kuasa } \\
\text { dua }\end{array}$ & $d f$ & $\boldsymbol{p}$ & \multicolumn{3}{c}{\begin{tabular}{c} 
Epsilon \\
\cline { 5 - 7 }
\end{tabular}} \\
\hline Ujian & 0.90 & 2.54 & 2 & 0.28 & 0.91 & 0.98 & 0.50 \\
\hline
\end{tabular}

Pada aras kesignifikan 0.05

Jadual 11: Keputusan Ujian Univariate untuk Min Konstruk Mengusul Periksa Andaian

\begin{tabular}{lccccccc}
\hline Kesan & Andaian dipatuhi & $\begin{array}{c}\text { Jumlah kuasa } \\
\text { Dua Jenis III }\end{array}$ & df & $\begin{array}{c}\text { Kuasa } \\
\text { dua min }\end{array}$ & $\boldsymbol{F}$ & $\boldsymbol{p}$ & $\begin{array}{c}\text { Partial eta } \\
\text { squared }\end{array}$ \\
\hline Andaian & 1017.31 & 2 & 508.65 & 111.64 & 0.00 & 0.82 \\
& Ralat & 218.69 & 48 & 4.56 & & & \\
\hline
\end{tabular}


Jadual 12: Keputusan Ujian Post Hoc Bonferroni Min Konstruk Mengusul Periksa Andaian

\begin{tabular}{|c|c|c|c|c|c|c|}
\hline & & $\begin{array}{c}\text { Perbezaan } \\
\text { Min }\end{array}$ & Ralat & $P$ & $\begin{array}{r}95 \% \\
\text { keyak } \\
\text { per } \\
\end{array}$ & $\begin{array}{l}\text { Ing } \\
\text { bagi } \\
\text { an }\end{array}$ \\
\hline & & & & & Bawah & Atas \\
\hline Ujian Pra & Ujian Pasca & -8.80 & 0.62 & 0.00 & -10.39 & -7.21 \\
\hline & Ujian Lanjutan & -6.12 & 0.50 & 0.00 & -7.42 & -4.82 \\
\hline Ujian Pasca & Ujian Pra & 8.80 & 0.62 & 0.00 & 7.21 & 10.39 \\
\hline & Ujian Lanjutan & 2.68 & 0.68 & 0.00 & 0.94 & 4.42 \\
\hline Ujian Lanjutan & Ujian Pra & 6.12 & 0.50 & 0.00 & 4.82 & 7.42 \\
\hline & Ujian Pasca & -2.68 & 0.68 & 0.00 & -4.42 & -0.94 \\
\hline
\end{tabular}

Berdasarkan estimated marginal means.

*Perbezaan min adalah signifikan pada aras 0.05

\section{Konstruk mengusul membuat deduksi}

Min ujian pasca konstruk membuat deduksi $(M=12.20, S D=3.49)$ adalah lebih tinggi berbanding dengan min ujian pra $(M=5.04, S D=1.97)$ dan ujian lanjutan $(M=8.76, S D=1.96)$. Keputusan ujian Multivariate pada Jadual 13 menunjukkan terdapat kesan ujian terhadap konstruk membuat deduksi yang signifikan (Wilks Lambda $=0.14, F(2,23)=68.80, \mathrm{p}<0.05, \pi^{2}=0.86$ ) iaitu saiz kesan sangat besar (Cohen, 1988). Di samping itu, keputusan ujian kesferaan Mauchly yang tidak signifikan $(p=0.40)$ pada Jadual 14 menunjukkan bahawa andaian kesferaan matriks varians adalah dipatuhi, maka keputusan ujian univariate pada Jadual 15 menunjukkan bahawa terdapat kesan ujian yang signifikan terhadap konstruk membuat deduksi $\left(F(2,48)=81.19, \mathrm{p}<0.05, \pi^{2}=0.78\right)$. Seterusnya, dapatan ujian Post Hoc Bonferroni pada Jadual 16 menunjukkan bahawa terdapat perbezaan yang signifikan antara ujian pra, ujian pasca dan ujian lanjutan terhadap min konstruk membuat deduksi. Oleh itu, hipotesis nol $\mathrm{H}_{\mathrm{olc}}$ berjaya ditolak iaitu terdapat perbezaan yang signifikan antara ujian pra, ujian pasca dan ujian lanjutan terhadap min konstruk membuat deduksi. Maka, terdapat kesan kekekalan terhadap konstruk membuat deduksi dalam kajian ini.

Jadual 13:Keputusan Ujian Multivariate untuk Min Konstruk Membuat Deduksi

\begin{tabular}{cccccccc}
\hline Kesan & Nilai & $\boldsymbol{F}$ & $\begin{array}{c}\text { Hipotesis } \\
\boldsymbol{d f}\end{array}$ & $\begin{array}{c}\text { Ralat } \\
\boldsymbol{d f}\end{array}$ & $\boldsymbol{p}$ & $\begin{array}{c}\text { Partial eta } \\
\text { squared }\end{array}$ \\
\hline Andaian & $\begin{array}{c}\text { Wilks' } \\
\text { Lambda }\end{array}$ & 0.14 & 68.80 & 2.00 & 23.00 & 0.00 & 0.86 \\
& & & & & & \\
\hline
\end{tabular}

Jadual 14: Keputusan ujian Mauchly's $W$ Min Konstruk Membuat Deduksi

\begin{tabular}{cccccccc}
\hline $\begin{array}{c}\text { Kesan } \\
\text { dalam } \\
\text { subjek }\end{array}$ & $\begin{array}{c}\text { Mauchly's } \\
W\end{array}$ & $\begin{array}{c}\text { Khi kuasa } \\
\text { dua }\end{array}$ & df & $p$ & \multicolumn{3}{c}{\begin{tabular}{c} 
Epsilon \\
\cline { 5 - 7 }
\end{tabular}} \\
\hline Ujian & 0.76 & 6.42 & 2 & 0.40 & 0.80 & 0.85 & 0.50 \\
\end{tabular}

Pada aras kesignifikan 0.05 
Jadual 15: Keputusan Ujian Univariate untuk Min Konstruk Membuat Deduksi

\begin{tabular}{llcccccc}
\hline Kesan & Andaian dipatuhi & $\begin{array}{c}\text { Jumlah kuasa } \\
\text { Dua Jenis III }\end{array}$ & df & $\begin{array}{c}\text { Kuasa } \\
\text { dua min }\end{array}$ & $\boldsymbol{F}$ & $\boldsymbol{p}$ & $\begin{array}{c}\text { Partial eta } \\
\text { squared }\end{array}$ \\
\hline Andaian & 641.15 & 2 & 320.57 & 81.19 & 0.00 & 0.77 \\
& Ralat & 189.52 & 48 & 3.95 & & & \\
\hline
\end{tabular}

Jadual 16: Keputusan Ujian Post Hoc Bonferroni Min Konstruk Membuat Deduksi

\begin{tabular}{llccccc}
\hline & & $\begin{array}{c}\text { Perbezaan } \\
\text { Min }\end{array}$ & Ralat & $\boldsymbol{P}$ & \multicolumn{2}{c}{$\begin{array}{c}\text { 95\% selang } \\
\text { keyakinan bagi } \\
\text { perbezaan }\end{array}$} \\
\cline { 6 - 8 } & & & & & \multicolumn{2}{c}{$\begin{array}{c}\text { Bawah } \\
\text { Ajian Pra }\end{array}$} \\
& Ujian Pasca & -7.16 & 0.65 & 0.00 & -8.84 & -5.48 \\
& Ujian Lanjutan & -3.72 & 0.41 & 0.00 & -4.77 & -2.67 \\
\hline Ujian Pasca & Ujian Pra & 7.16 & 0.65 & 0.00 & 5.48 & 8.84 \\
& Ujian Lanjutan & 3.44 & 0.60 & 0.00 & 1.90 & 4.98 \\
\hline Ujian Lanjutan & Ujian Pra & 3.72 & 0.41 & 0.00 & 2.67 & 4.77 \\
& Ujian Pasca & -3.44 & 0.60 & 0.00 & -4.98 & -1.90 \\
\hline
\end{tabular}

Berdasarkan estimated marginal means.

*Perbezaan min adalah signifikan pada aras 0.05

\section{Konstruk mengusul membuat interpretasi}

Min ujian pasca konstruk membuat interpretasi $(M=13.84, S D=2.30)$ adalah lebih tinggi berbanding dengan min ujian pra $(M=5.04, S D=2.07)$ dan ujian lanjutan $(M=10.80, S D=1.47)$. Keputusan ujian Multivariate pada Jadual 17 menunjukkan terdapat kesan ujian terhadap konstruk membuat interpretasi yang signifikan (Wilks Lambda $=0.07, F(2,23)=148.10, \mathrm{p}<0.05, \pi^{2}=0.93$ ) iaitu saiz kesan sangat besar (Cohen, 1988). Di samping itu, keputusan ujian kesferaan Mauchly yang tidak signifikan $(p=0.99)$ pada Jadual 18 menunjukkan bahawa andaian kesferaan matriks varians adalah dipatuhi, maka keputusan ujian univariate pada Jadual 19 menunjukkan bahawa terdapat kesan ujian yang signifikan terhadap konstruk membuat interpretasi $\left(F(2,48)=154.48, \mathrm{p}<0.05, \pi^{2}=0.87\right)$. Seterusnya, dapatan ujian Post Hoc Bonferroni pada Jadual 20 menunjukkan bahawa terdapat perbezaan yang signifikan antara ujian pra, ujian pasca dan ujian lanjutan terhadap min konstruk membuat interpretasi. Oleh itu, hipotesis nol $\mathrm{H}_{\text {old }}$ berjaya ditolak iaitu terdapat perbezaan yang signifikan antara ujian pra, ujian pasca dan ujian lanjutan terhadap min konstruk membuat interpretasi. Maka, terdapat kesan kekekalan terhadap konstruk membuat interpretasi dalam kajian ini.

Jadual 17: Keputusan Ujian Multivariate untuk Min Konstruk Membuat Interpretasi

\begin{tabular}{|c|c|c|c|c|c|c|c|}
\hline Kesan & & Nilai & $F$ & $\begin{array}{l}\text { Hipotesis } \\
\qquad d f\end{array}$ & $\begin{array}{c}\text { Ralat } \\
d f\end{array}$ & $p$ & $\begin{array}{c}\text { Partial eta } \\
\text { squared }\end{array}$ \\
\hline Andaian & $\begin{array}{c}\text { Wilks' } \\
\text { Lambda }\end{array}$ & 0.07 & 148.10 & 2.00 & 23.00 & 0.00 & 0.93 \\
\hline
\end{tabular}

Jadual 18: Keputusan ujian Mauchly's W Min Konstruk Membuat Interpretasi

\begin{tabular}{cccccccc}
\hline $\begin{array}{c}\text { Kesan } \\
\text { dalam } \\
\text { subjek }\end{array}$ & $\begin{array}{c}\text { Mauchly's } \\
\boldsymbol{W}\end{array}$ & $\begin{array}{c}\text { Khi kuasa } \\
\text { dua }\end{array}$ & $\boldsymbol{d f}$ & $\boldsymbol{p}$ & \multicolumn{3}{c}{\begin{tabular}{c} 
Epsilon \\
\cline { 4 - 7 }
\end{tabular}} \\
\hline Ujian & 1.00 & 0.01 & 2 & 0.99 & 1.00 & 1.00 & 0.50 \\
\hline
\end{tabular}


Pada aras kesignifikan 0.05

Jadual 19: Keputusan Ujian Univariate untuk Min Konstruk Membuat Interpretasi

\begin{tabular}{llcccccc}
\hline Kesan & $\begin{array}{c}\text { Jumlah } \\
\text { kuasa Dua } \\
\text { Jenis III }\end{array}$ & df & $\begin{array}{c}\text { Kuasa } \\
\text { dua min }\end{array}$ & $\boldsymbol{F}$ & $\boldsymbol{p}$ & $\begin{array}{c}\text { Partial } \\
\text { eta } \\
\text { squared }\end{array}$ \\
\hline Andaian & Andaian dipatuhi & 998.83 & 2 & 499.41 & 154.48 & 0.00 & 0.87 \\
\hline & Ralat & 155.17 & 48 & 3.23 & & & \\
\hline
\end{tabular}

Jadual 20: Keputusan Ujian Post Hoc Bonferroni Min Konstruk Membuat Interpretasi

\begin{tabular}{llccccc}
\hline & & $\begin{array}{c}\text { Perbezaan } \\
\text { Min }\end{array}$ & Ralat & $\boldsymbol{P}$ & \multicolumn{2}{c}{$\begin{array}{c}\text { 95\% selang } \\
\text { keyakinan bagi } \\
\text { perbezaan }\end{array}$} \\
\hline Ujian Pra & Ujian Pasca & -8.80 & 0.51 & 0.00 & -10.10 & -7.50 \\
& Ujian Lanjutan & -5.76 & 0.51 & 0.00 & -7.08 & -4.44 \\
\hline Ujian Pasca & Ujian Pra & 8.80 & 0.51 & 0.00 & 7.50 & 10.10 \\
& Ujian Lanjutan & 3.04 & 0.51 & 0.00 & 1.74 & 4.34 \\
\hline Ujian Lanjutan & Ujian Pra & 5.76 & 0.51 & 0.00 & 4.44 & 7.08 \\
& Ujian Pasca & -3.04 & 0.51 & 0.00 & -4.34 & -1.74 \\
\hline
\end{tabular}

Berdasarkan estimated marginal means.

*Perbezaan min adalah signifikan pada aras 0.05

\section{Konstruk penilaian hujah}

Min ujian pasca konstruk penilaian hujah $(M=13.20, S D=3.16)$ adalah lebih tinggi berbanding dengan min ujian pra $(M=5.00, S D=1.83)$ dan ujian lanjutan $(M=10.12, S D=1.79)$. Keputusan ujian Multivariate pada Jadual 21 menunjukkan terdapat kesan ujian terhadap konstruk penilaian hujah yang signifikan (Wilks Lambda=0.10, $F(2,23)=105.21, \mathrm{p}<0.05, \pi^{2}=0.90$ ) iaitu saiz kesan sangat besar (Cohen, 1988). Di samping itu, keputusan ujian kesferaan Mauchly yang tidak signifikan $(p=0.29)$ pada Jadual 22 menunjukkan bahawa andaian kesferaan matriks varians adalah dipatuhi, maka keputusan ujian univariate pada Jadual 23 menunjukkan bahawa terdapat kesan ujian yang signifikan terhadap konstruk penilaian hujah $\left(F(2,48)=93.23, \mathrm{p}<0.05, \pi^{2}=0.80\right)$. Seterusnya, dapatan ujian Post Hoc Bonferroni pada Jadual 24 menunjukkan bahawa terdapat perbezaan yang signifikan antara ujian pra, ujian pasca dan ujian lanjutan terhadap min konstruk penilaian hujah. Oleh itu, hipotesis nol $\mathrm{H}_{\mathrm{ole}}$ berjaya ditolak iaitu terdapat perbezaan yang signifikan antara ujian pra, ujian pasca dan ujian lanjutan terhadap min konstruk penilaian hujah. Maka, terdapat kesan kekekalan terhadap konstruk penilaian hujah dalam kajian ini.

Jadual 21: Keputusan Ujian Multivariate untuk Min Konstruk Penilaian Hujah

\begin{tabular}{|c|c|c|c|c|c|c|c|}
\hline Kesan & & Nilai & $F$ & $\begin{array}{c}\text { Hipotesis } \\
d f\end{array}$ & $\begin{array}{c}\text { Ralat } \\
d f\end{array}$ & $p$ & $\begin{array}{c}\text { Partial eta } \\
\text { squared }\end{array}$ \\
\hline Andaian & Wilks' Lambda & 0.90 & 105.21 & 2.00 & 23.00 & 0.00 & 0.90 \\
\hline
\end{tabular}


Jadual 22: Keputusan ujian Mauchly’s W Min Konstruk Penilaian Hujah

\begin{tabular}{cccccccc}
\hline $\begin{array}{c}\text { Kesan } \\
\text { dalam } \\
\text { subjek }\end{array}$ & $\begin{array}{c}\text { Mauchly's } \\
W\end{array}$ & $\begin{array}{c}\text { Khi kuasa } \\
\text { dua }\end{array}$ & df & $p$ & \multicolumn{3}{c}{ Epsilon } \\
\hline Ujian & 0.90 & 2.46 & 2 & 0.29 & 0.91 & 0.98 & 0.50 \\
\hline
\end{tabular}

Pada aras kesignifikan 0.05

Jadual 23: Keputusan Ujian Univariate untuk Min Konstruk Penilaian Hujah

\begin{tabular}{clcccccc}
\hline Kesan & Jumlah & df & $\begin{array}{c}\text { Kuasa } \\
\text { kuasa Dua } \\
\text { Jenis III }\end{array}$ & $\begin{array}{c}\text { min } \\
\text { min }\end{array}$ & p & $\begin{array}{c}\text { Partial } \\
\text { eta } \\
\text { squared }\end{array}$ \\
\hline Andaian & $\begin{array}{l}\text { Andaian } \\
\text { dipatuhi }\end{array}$ & 857.84 & 2 & 428.92 & 93.23 & 0.00 & 0.80 \\
\hline & Ralat & 220.83 & 48 & 4.60 & & & \\
\hline
\end{tabular}

Jadual 24: Keputusan Ujian Post Hoc Bonferroni Min Konstruk Penilaian Hujah

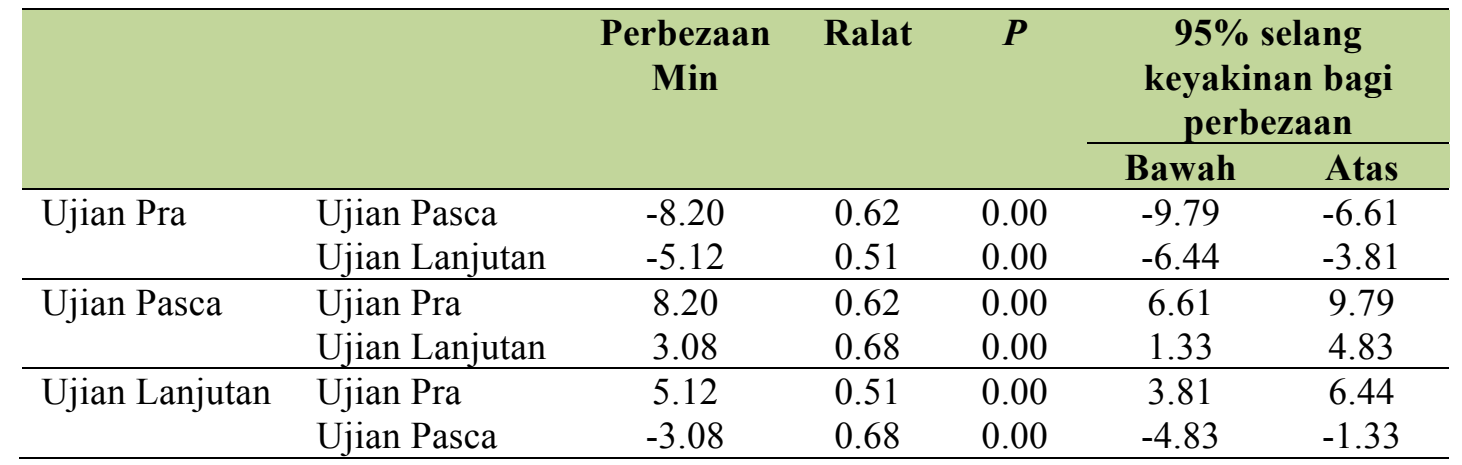

Berdasarkan estimated marginal means.

*Perbezaan min adalah signifikan pada aras 0.05

\section{Perbincangan Kajian}

Dapatan kajian ini yang menunjukkan teknik Peer Instruction dengan analisis sumber-sumber sejarah didapati berkesan terhadap kemahiran berfikir kritikal dalam kalangan murid adalah selaras dengan dapatan kajian-kajian lepas seperti kajian Firdaus, Ismail Kailani, Md Nor Bakar dan Bakry (2015), kajian Nitta, (2010) dan kajian Porter, Bailey, Simon, Cutts dan Zingaro, (2011) yang telah melaporkan bahawa penggunaan teknik Peer Instruction dapat meningkatkan pemahaman konseptual dan kemahiran berfikir kritis dalam kalangan murid. Hal ini kerana gaya dan cara berfikir yang berbezabeza telah membolehkan murid-murid dapat meningkatkan kefahaman kandungan sejarah dengan membuat suatu perbandingan, pentafsiran dan penilaian yang kritis terhadap maklumat-maklumat sejarah yang diperolehi daripada proses analisis sumber-sumber sejarah (Macedo-Rouet, Braasch, Britt \& Rouet, 2013; Cowgill \& Waring, 2017; Patterson et al, 2012). Tambahan pula, peningkatan kemahiran berfikir kritikal yang signifikan berdasarkan intervensi yang dilaksanakan dalam mata pelajaran sejarah dalam kajian ini adalah konsisten dengan dapatan kajian Nurchayno dan Djono (2018) dan kajian Isjoni (2017) yang telah melaporkan bahawa aplikasi model pembelajaran penerokaan dan model pembelajaran koperatif adalah berkesan dan efektif untuk meningkatkan kemahiran berfikir kritikal sebagai salah satu langkah perubahan dalam strategi pengajaran sedia ada disebabkan oleh melibatkan aplikasi teknik pembelajaran tertentu dalam mata pelajaran sejarah. 
Sungguhpun begitu, kekekalan kemahiran berfikir kritis yang berkesan dalam kajian ini adalah konsisten kajian Darlund dan Carmichael, (2012), kajian Rahimawati Abd. Rahim (2017), kajian Ahlam dan Hala, (2014) dan kajian Dresner, Rivero, Fuccillo dan Chang, (2014) yang menjelaskan bahawa intervensi yang dijalankan dalam pendidikan sains dapat meningkatkan kekekalan jangka panjang terhadap kemahiran berfikir kritis. Hal ini kerana perancangan yang rapi terhadap suatu kaedah pengajaran adalah berupaya untuk meningkatkan kemahiran berfikir kritis yang dirujuk sebagai penerokaan mendalam untuk mengkaji suatu situasi, fenomena, persoalan atau masalah bagi menjana suatu kesimpulan yang kritis berdasarkan pengalaman, bahan bacaan, pemerhatian, pendengaran dan sebagainya (Noriati A. Rashid, Boon, \& Sharifah Fakhriah Syed Ahmad, 2009). Pendapat ini adalah bertepatan dengan pelaksanaan teknik Peer Instruction dengan analisis sumber-sumber sejarah dalam mata pelajaran sejarah yang telah menyediakan ruang dan peluang kepada murid-murid untuk meneroka dan mengekalkan tahap keintelektualan dan pemprosesan kognitif mereka bagi menilai dan mempertimbangkan kandungan sumber sejarah yang dianalisis (Nokes, 2014; Merkt, Werner \& Wagner, 2017).

Tambahan pula, konstruk-konstruk dalam kemahiran berfikir kritikal seperti membuat inferens, mengusul periksa andaian, membuat deduksi, membuat interpretasi, dan penilaian hujah yang berkesan dalam kajian ini adalah bertentangan dengan kajian Sarimah Kamrin dan Shahrom Noordin (2008) yang mendapati bahawa tahap bagi konstruk-konstruk dalam kemahiran berfikir kritis berada antara tahap lemah, sederhana dan baik iaitu konstruk membuat inferens berada pada tahap rendah, konstruk membuat deduksi, membuat interpretasi, dan penilaian hujah berada pada tahap sederhana dan hanya konstruk mengusul periksa sahaja yang berada pada tahap baik. Sungguhpun begitu, peningkatan bagi setiap konstruk dalam kemahiran berfikir kritikal dalam kajian ini antara ujian pra, ujian pasca dalam kajian ini adalah konsisten dengan dapatan kajian Sabaria Juremi (2003) yang telah melaporkan muridmurid yang mengikuti kaedah pembelajaran berasaskan masalah dalam pendidikan biologi dapat meningkatkan kelima-lima konstruk iaitu membuat inferens, mengusul periksa andaian, membuat deduksi, membuat interpretasi, dan penilaiah hujah secara signifikan antara kumpulan eksperimen dan kawalan bagi murid-murid yang mengambil mata pelajaran Biologi. Hal ini kerana murid-murid dapat meneliti dan membuat pertimbangan yang munasabah sebelum suatu kesimpulan dibuat berdasarkan idea, bukti, cadangan, tindakan, dan sebagainya yang membolehkan kawalan terhadap metakognitif dapat dilakukan dengan baik.

\section{Kesimpulan}

Kesimpulannya, dapatan kajian ini telah menunjukkan bahawa teknik Peer Instruction dengan analisis sumber-sumber sejarah adalah berkesan terhadap kekekalan kemahiran berfikir kritikal dalam kalangan murid. Kajian ini diharapkan dapat memberi sumbangan kepada guru-guru sejarah dalam mencadangkan dan menyediakan salah satu kaedah pengajaran dan pembelajaran melalui teknik Peer Instruction dengan analisis sumber-sumber sejarah terhadap penjanaan kematangan murid berfikir secara kritikal selaras dengan keperluan untuk melahirkan individu murid yang mampu berkembang maju dan bersaing pada peringkat global serta berupaya menghadapi cabaran masa depan secara holistik melalui proses transformasi sistem pendidikan yang menyeluruh dan sistematik. Justeru, semua pihak perlu berkerjasama bagi memastikan setiap murid dapat menguasai kemahiran-kemahiran kognitif seperti keupayaan berfikir secara kritikal, kreatif, logik, induktif dan deduktif semaksimumnya seperti yang dihasratkan dalam pelan aspirasi negara.

\section{Rujukan}

Ahlam, E. S., \& Hala, G. (2014). Impact of Problem Based Learning on Students Critical Thinking Dispositions, Knowledge Acquasition and retention. Journal of Education and Practice, 5(1), 7485.

Barton, K.C. (2005). Primary sources in history: Breaking through the myths. Phi Delta Kappan, $86(10), 745-753$.

Beyer, B. (1995). Critical thinking. Bloomington: Phi Delta Kappa International Foundation. 
Burkholder, P. (2014). A Content Means To A Critical Thinking End: Group Quizzing In History Surveys. Journal the History Teacher, 47(4).

Cohen, J. (1988). Statistical Power Analysis for the Behavioral Sciences $\left(2^{\text {nd }}\right.$ Ed). Hilsdale, New Jersey: Lawrence Erlbaum Associates Publishers.

Cohen, L., Manion, L., \& Morrison, K. (2007). Research Methods in Education (5 ${ }^{\text {th }}$ Edition). London: Routledge Falmer.

Cortright, R.N., Collins, H.L \& DiCarlo, S.E. (2005). Peer Instruction enhanced meaningful learning; abilitiy to solve novel problems. Adv Physiol Educ, 29, 107-111.

Cowgill II, D.A., \& Waring, S.M. (2017). Historical Thinking: An Evaluation of Student and Teacher Ability to Analyze Sources. Journal of Social Studies Education Research, 8(1), 115-145.

Crouch, C.H., \& Mazur, E. (2001). Peer Instruction: Ten Years of Experiences and Result. American Journal of Physics, 69, 670-977.

Darlund, D.C., \& Carmichael, J.S. (2012). Long Term Retention of Knowledge and critical thinking skills in development Biology. Journal Microbiology \& Biology Education, 13(2), 125-132.

Dresner, M, Rivera, C.D., Fuccillo, K.K., \& Chang, H. (2014). Improving higher-order thinking and knowledge retention in environmental science teaching. Bioscience, 64(1), 40-48.

Edmonds, M., Hull, J.A., Janik, E.L., \& Rylance, K. (2005). History \& Critical Thinking: A Handbook for using historical documents to improve students thinking skills in the secondary grades. Madisen: Wiseonsin Historical Society.

Firdaus, Ismail Kailani, Md Nor Bakar \& Bakry. (2015). Developing critical thinking skills of students in mathematics learning. Journal of Education and Learning, 9(3), 226-236.

Gough, D. (1991). Thinking about thinking. Research Roundup, 7(2), 1-4.

Halpern, D.F. (1998). Teaching critical thinking for transfer across domains: Disposition, skills, structure training and metacognitive monitoring. American Psychologist, 55(4), 449-455.

Hamidah Maidinsah, Farah Nabillah, Mohamed Jizad, Maslizah Ab. Wahab \& Balkish Osman, (2019). Attributes affecting students' ability in thinking skills. Journal Pendidikan Malaysia, 44(2), 84-100.

Herreid, C.F., Schiller, N.A., \& Herreid, K.F. (2012). Science stories: Using case dtudies to teach critical thinking. Arlington: NSTA Press.

Herrnstein, R.J., Nickerson, R.S., Sanchez, M.D., \& Swetz, J.A. (1986). Teaching thinking skills. American Psychologist, 41(11), 1279-1289.

Isjoni. (2017). The implementation of cooperative learning model of critical thinking skills in the history subject at SMA Pekanbaru. International Journal of Educational Best Practices, 1(1), 3856.

Karma, E.H \& Ghida, M. (2007). Validating the Watson Glaser Critical Thinking Appraisal. Higher Education, 54, 361-383.

Kementerian Pendidikan Malaysia. (2013). Pelan Pembangunan Pendidikan Malaysia 2013-2025. Putrajaya: Kementerian Pendidikan Malaysia.

Lasry, N., Mazur, E., \& Watkins, J. (2008). Peer Instruction: from Harvard to the two years college. American Journals of Physics, 76(11), 1066-1069.

Lucas, A. (2009). Using Peer instruction and I-Clikers to enhance student participation in calculus. Primus, 19, 219-231.

Macedo-Rouet, M., Braasch, J.L.G., Britt, M.A \& Rouet, J.F. (2013). Teaching Fourth and Fifth Graders to Evaluate Information Sources During Text Comprehension. Cognition and Instruction, 31(2), 204-226, 204-226.

Mazur, E. (1997). Peer Instruction: A user manual. Upper Saddle River: Prentice Hall.

Merkt, M., Werner, M., \& Wagner, W. (2017). Historical thinking skills and mastery of multiple documents tasks. Learning and Individual Differences, 54, 135-146

Mohd Fadzil Mohd Rosdi, Suhaida Abdul Kadir \& Mohd Ibrahim Nazri. (2017). Tahap kemahiran dan kecenderungan pemikiran kritis murid tingkatan dua dalam mata pelajaran kemahiran hidup bersepadu (KHB) di negeri Kedah dan hubungannya. Asia Pacific Journal of Educators and Education, 32, 45-60.

Mohd Rozaidi Ismai, Roslina Abdul Aziz \& Zamnah Husin. (2007). The use of critical thinking skills among university ESL students. In: The Second Biennial International Conference on teaching and learning of English in Asia: Exploringnew frontiers (TELiA2), 14-16 Jun 2007, Holiday Villa 
Beach \& Spa Resort, Langkawi. Faculty of Comunication and Modern Languages, Universiti Utara Malaysia, Sintok, 1-14.

Mulnix, J.W. (2010). Thinking critically about critical thinking. Educational Philosophy and Theory, 1-16. Doi:10.111/j.1469.5812.2010.00673.x

Nitta, H. (2010). Mathematics theory of peer instructions dynamics. Physical Review Special TopicsPhysics Education Research, 6(2), 1-4.

Nokes, J.D. (2014). Elementary students' Roles and Epistemic Stances during Document Based History Lessons. Theory \& Research in Social Education, 42, 375-413.

Noriati A. Rashid, Boon, P.Y., \& Sharifah akhriah Syed Ahmad. (2009). Murid dan Alam Belajar. Selangor: Oxford Fajar Sdn Bhd.

Nunnally, J.C. (1978). Psychometrie Theory ( $2^{\text {nd }}$ ed). New York: McGraw Hill.

Nurchayno, E. \& Djono, L.A.S. (2018). The implementation of discovery learning model with scientific learning to improve student critical thinking in history subject. International journal of multicultural and multireligious understanding, 5(3), 106-112.

Nurul Shida Noni \& Abdul Halim Abdullah. (2018). Assessing critical thinking skills in polytechnic. International Journal of Engineering \& Technology, 7(2,29), 506-510.

Patterson, N.C., Lucas, A.G., \& Kithinji, M. (2012). Higher Order Thinking in Social Studies: An analysis of Primary Source Document Use. Social studies Research and Practice, 7(2), 68-85.

Porter, L., Bailey, L.C., Simon, B., Cutts, Q., \& Zingaro, D. (2011). A multi-classroom report on the value of peer instruction. In Proceedings of the $16^{\text {th }}$ Annual Joint Conference on Innovation and Technology in Computer Science Education, June, Darmstadt, Germany.

Pusat Perkembangan Kurikulum. (2003). Huraian Sukatan Pelajaran Sejarah Tingkatan Empat. Kuala Lumpur: Kementerian Pendidikan Malaysia.

Rahimawati Abd. Rahim. (2017). Kesan pembelajaran sains berasaskan isu sosiosaintifik dengan nilai islam ke atas sikap, nilai murni dan kemahiran berfikir kritis pelajar sekolah menengah tingkatan empat. Tesis Doktor Falsafah, Universiti Sains Malaysia.

Rao, S.P., \& DiCarlo, S.E. (2000). Peer Instructions improves performance on quizzes. Adv Physiol Educ, 24, 51-55.

Rosnani Hashim. (2002). Investigation on the teaching of critical and creative thinking in Malaysia. Jurnal Pendidikan Islam, 10(1), 39-56.

Sabaria Juremi. (2003). Kesan penggunaan kaedah pembelajaran berasaskan masalah terhadap kemahiran berfikir kritis, kreatif, proses sains dan pencapaian biologi. Tesis Doktor Falsafah, Universiti Sains Malaysia.

Sarimah Kamrin \& Shaharom Noordin. (2008). Tahap penguasaan kemahiran berfikir kritis pelajar sains tingkatan empat. Jurnal pendidikan Universiti Teknologi Malaysia, 13, 58-72.

Snyder, L.G \& Snyder, M.J. (2008). Teaching critical thinking and problem solving skills. The Delta Phi Epsilon Journal, 1(2), 90-99.

Sullivan, R (2009). Principles for Constructing Good Clicker Questions: Going Beyond Rote Learning and Stimulating Active Engagement with Course Content. Journal of Educational Technology Systems, 37(3), 335-347.

Tolga, G. (2012). The effects of peer instruction on student's conceptual learning and motivation. Asia pacific Forum SciLearn Teach, 13(1), 1-17.

VanDen, B. I., Admiral, W., \& Pilot, A. (2006). Design Principles and Outcome of Peer Assessment in Higher Education. Studies in Higher Education, 31, 341-356

Waring, S.M., \& Robinson, K.S. (2011). Developing critical and historical thinking skills in middle grade social studies. Middle School Journal, September, 22-28.

Watson, G., \& Glaser, E.M. (1980). Watson-Glaser Critical Thinking Appraisal Manual. Psychological Corporation. 